\title{
Pelargonium endlicherianum Fenzl. Root Extract Suppresses Cell Proliferation of Prostate Cancer Cells ${ }^{\dagger}$
}

\author{
Selda Eren 1, Hatice Bekci 2, Guzide Satır Basaran ${ }^{3}$, Gokce Seker Karatoprak ${ }^{4}$ and \\ Ahmet Cumaoglu ${ }^{3, *}$ \\ 1 Faculty of Pharmacy, Erciyes University, Kayseri 38030, Turkey; yagmurselda@windowslife.com \\ 2 Department of Food Engineering, Erciyes University Engineering Faculty, Kayseri 38030, Turkey; \\ hatice_bekci@hotmail.com \\ 3 Department of Biochemistry, Faculty of Pharmacy, Erciyes University, Kayseri 38030, Turkey; \\ basarangzd@gmail.com \\ 4 Department of Pharmacognocy, Faculty of Pharmacy, Erciyes University, Kayseri 38030, Turkey; \\ gskaratoprak@gmail.com \\ * Correspondence: ahmetcumaoglu@yahoo.com; Tel.: +90-5333405104 \\ + Presented at the 2nd International Conference on Natural Products for Cancer Prevention and Therapy, \\ Kayseri, Turkey, 8-11 November 2017.
}

Published: 15 November 2017

\begin{abstract}
Cancer cells are refractory to most forms of chemotherapy. Conventional and alternative drugs, such as herbal extracts, have been developed to target cancer cells. This study aims to test the cytotoxic effects of Pelargonium endlicherianum root extracts on prostate cancer cells. In vitro cytotoxic activities of the methanolic and ethanolic root extracts $(0-150 \mu \mathrm{g} / \mathrm{mL})$ were screened against androgen dependent independent (PC-3) prostate cancer cell lines by MTT assay. Ethanolic root extract induced a significant decrease in cell viability characterized by $100<$ IC50 $<150 \mu \mathrm{g} / \mathrm{mL}$. The results of this study support the efficacy of $P$. endlicherianum as an anticancer agent for prostate cancer and a potential adjuvant treatment to current chemotherapeutic agents used in the treatment of prostate tumors. Further studies of the effects of individual flavonoids alone and in combination with each other and with currently used therapies are needed.
\end{abstract}

Keywords: Pelargonium endlicherianum; cancer; MTT assay

Conflicts of Interest: The authors declare no conflict of interest.

(C) 2017 by the authors. Licensee MDPI, Basel, Switzerland. This article is an open access article distributed under the terms and conditions of the Creative Commons Attribution (CC BY) license (http://creativecommons.org/licenses/by/4.0/). 